\title{
Recasting Industrial Relations: Productivity, Place and the Queensland Coal Industry, 2001-2013
}

For most of the twentieth century, Australian workplaces conducted their business under the oversight of a centralized arbitration system that gave primacy to wage equity and conflict minimization. As this system unravelled during the 1980s, however, the issue of productivity enhancement assumed greater significance, it being widely assumed that different industrial relations settings could either enhance or restrict productivity. In Australia, as elsewhere, many supporters of collective bargaining and trade unionism argued that reductions in managerial prerogative could have positive productivity effects, an Australian Council of Trade Union report suggesting in 1987 that: 'Achieving the maximum possible productivity is impossible without advanced forms of industrial democracy (ACTU / TDC, 1987: 135). Over time, this view was increasingly supplanted by an opposing perspective, which held that productivity was best advanced by reducing union influence at the workplace so as to allow for individual bargaining between employers and workers. Restating this view, the Productivity Commission (2009: xiv-xv) advised the Commonwealth Parliament that the 'key lessons' to be drawn from the Australian experience of the last few decades is that productivity was best advanced by economic and labour reforms that 'heightened competitive pressures' on businesses and workers. The prime historical evidence for this conclusion, the Productivity Commission held, is found in the productivity 'surge' that occurred between 1993-94 and 1998-99, which saw labour productivity grow at an annualized rate of 3.2 per cent. Not only was this outcome better than that found in 'any comparable period in the previous 30 years' (Dolman, Lu and Rahman, 2006: 36), it was also temporally correlated with major policy adjustments - the introduction of enterprise bargaining in 1991, non-union bargaining in 1993 and the Workplace Relations Act, 1996 (WRA). Unsurprisingly, this correlation was widely seen as causation. There have, nevertheless, been sceptics, most notably Keith Hancock (Hancock, 2012; Hancock et al., 2007) and David Peetz (2006, 2012), the latter observing that there is in fact 'no inherent relationship' between industrial relations settings and the 'growth of productivity' (Peetz, 2006: 49) More recent events in the national economy lend credence to this more circumspect view with national labour productivity falling to half the long-term trend of 2.2 per cent after 2000 (Commonwealth Treasury, 2013: 50-51). 
To explore this debate about the link between productivity and industrial relations this study examines trends in the Queensland coal sector since 2001, drawing upon statistics for production and employment provided to it by both the Rent and Statistics Unit (R\&S) and the Mine Safety and Health Unit (S\&H) of the Queensland Department of Natural Resources and Mines (QDNRM); statistics that supplement those publicly available. Significantly, in the 1990s the Queensland coal industry seemed to provide strong evidence for the view that reducing union influence and centralized wage fixation provisions advanced productivity. Whereas, nationally, labour productivity advanced at 3.2 per cent per year between 1993-93 and 1998-99, in the Queensland coal industry it rose at an annualized rate of 17.6 per cent between $1995-96$ and $2000-01$. This saw per capita saleable output rise from 8830 tonnes to 16,579 tonnes per annum (Joint Coal Board and QDNRM, 2001: xx). Back then, one of the authors of this study concluded, in an article appearing in this journal (Bowden, 2000: 376), that 'a new work regime' had been established in coal mining, 'characterised by increased managerial control, increased work intensity, dramatic gains in productivity.' Yet, if this 'new work regime' was initially associated with rising productivity, in the ensuing decade an accentuation of this same regime produced falls in labour productivity that more than reversed all the previous gains. In short, the apparent link between industrial relations change and productivity in this industry turned out to be a chimera. As this study will indicate, between 2001-02 and 2011-12 annual saleable output per employee collapsed, falling by 67.9 per cent (QDNRM, 2002; QDNRM, 2013a). This left annual output per employee at 5323 tonnes - far less than that obtained in 1996. If we measure labour productivity on the basis of employment statistics collected by the QDNRM's Safety and Health Unit, which more accurately gauge both contractor and direct employee engagements, an even worse trend is revealed with annual output per employee falling to only 4455 tonnes (QDNRM-S\&H, 2013a). Similar trends are found when, again using statistics from QDNRM's Safety and Health Unit, we examine outcomes at four large Central Queensland open-cut mines (QDNRM-S\&H, 2013b).

The stark productivity declines which this study records leads inevitably to two questions. The first is: How can we explain these falls, given that the industrial relations settings in the industry were for most if not all of the post-2001 period - more favourable to employers than they had been in the years between 1996 and 2000, when productivity rose sharply? The answer to this conundrum is not to be found, this study argues, in factors such as increased overburden and declining resource quality identified by the Production Commission (2009, 2013; Topp et al., 2008). Instead, the only correlation 
that seems to hold true is that between the productivity and the state of the labour market. Since 1996, on every occasion that productivity rose (1996-2000 and 2011-2013), employment was falling. Conversely, when employment rose (2001-2011), productivity fell. Suggestively, rising employment was always associated with rising coal prices, while falling employment was always correlated with declining price. This coincidence of product and labour market circumstance meant that in times of falling price employers had both incentive and means (in the form of surplus labour) to enact changes that extracted greater labour effort from their workforce. Conversely, in times of rising price they had not only less means for taking action but also less incentive. The second question to present itself is: why did the employers not take actions to remedy the fall in productivity that must have become apparent to them by the mid-2000s? To this, two answers are provided. As indicated in Table 3 of this paper, declining physical outputs per employee were for most of the 2001 to 2011 period more than offset by rising prices, so that the value of the coal produced per person kept rising even though the amount rendered fell. The second answer to the question is that in coal mining, as in other industries, productivity often plays second fiddle to other factors. If the coal industry has failed to find a magic productivity elixir, a profound recasting of industrial relations has nevertheless occurred. At heart, it is argued, this involved a systematic employer attempt to overcome the social consequences that have followed from geologically-fixed supply, a factor that has historically manifested itself in strong community support for coal mining unions (Kerr and Siegel, 1954; Gollan, 1963). In consequence, decollectivization rather than productivity enhancement remained the constant. Since 2001, it is suggested, this involved two employer strategies. First, between 2001 and 2011, coal operators continued to displace the unionized workforce with contractors - a practice that was well in place before 2000 (Bowden, 2004; Waring, 2003). More recently, it has involved the introduction of a Fly-in, Fly-Out (FIFO) workforce into the Queensland industry, a practice that allows employers to circumvent not only the remnants of the unionized workforce but also the coal communities that have provided past sustenance to this workforce. The success of both gambits is indicated by the fact that union density in coal mining declined from 75.5 per cent to 39.8 per cent between 2001 and 2013 (ABS, 2002: 17; ABS, 2014: 14).

\section{Industrial Relations in Coal Mining: Markets, Productivity and Place}

The relationship between productivity and industrial relations has become an increasingly contentious one for Australian public policy. In the early 2000s, the correlation between major industrial relations 
changes (enterprise bargaining, the introduction of the WRA) and the 1990s 'productivity surge' was widely seen as causation (see Parham, 2013, for summary of this literature). However, the productivity 'surge' of the 1990s was followed by a marked 'productivity slump' between 2003-04 and 2011-12 (Parham, 2013: 463). This 'slump' lent support to those such as Peetz $(2006,2012)$ and Hancock (2012; Hancock et al., 2007) who argued that there is no intrinsic relationship between productivity and industrial relations, and that there are instead both 'high' and 'low' roads to increased productivity, the latter involving increased skill and employment involvement and the latter greater work intensity and job insecurity. In discounting the supposed long-term benefits of the 1990s 'surge', Hancock (2012: 296) also contended that - to the extent a positive relationship did exist between productivity growth and policy changes during the 1990s - it was due to the picking of 'low-hanging fruit'. Once picked, scope for further advances was largely exhausted. Peetz $(2006,2012)$ and Hancock (2012; Hancock et., 2007) also emphasize that there was, in fact, no uniform productivity 'surge' across the economy between 1993-94 and 1998-99. Instead, the national result reflected widely varying occurrences in a range of industries with the balance favouring above-trend growth only because of aberrant rises in particular industries (mining being one).

There is no doubt that recent trends in the Australian economy have curtailed support for simplistic linkages between productivity and industrial relations. In a recent study, Dean Parham (2013: 470) a former Productivity Commission staffer, conceded that: 'Productivity cannot be turned on like a tap.' Strong support remains, however, for the view that a labour relations environment that imposes few restrictions on management is most conducive to productivity advancement (Productivity Commission, 2009, 2013; Parham, 2004, 2009). The Productivity Commission, in particular, continues to argue that 'the unprecedented productivity growth' of the 1990s stemmed from 'enabling' policy, and that future gains will necessarily be associated with further labour market deregulation (Productivity Commission, 2009: xiv-xV; also Productivity Commission, 2013). Unfortunately for the holders of such opinion, trends in Australian mining have become increasingly problematic. In the 1990s, this industry was subject to particularly radical industrial relations change. The iron ore industry was largely deunionized (Ellem, 2002, 2004). As will be discussed in more detail below, the coal industry also experienced profound change once the Coal Industry Tribunal (CIT), which had previously provided the sector with regulatory oversight, was abolished in 1995; an event followed in the ensuing year by the election of the Howard Government and the passage of the WRA. With job 
numbers slashed, saleable output per employee in Queensland rose from 8830 tonnes to 16,579 tonnes per annum between 1995-96 and 2000-01 (Joint Coal Board \& QDNRM, 2001: 23). Such outcomes caused a Business Council of Australia study (2005: 25) to declare that the 'mining sector provides a clear and excellent example of the benefits of workplace reform.' However, since 2000 the mining sector has experienced productivity declines that are among the worst of any industry (Dolman, 2009: 249). Outcomes were particularly poor in coal mining, where a Productivity Commission study (Topp et al., 2008: 26) concluded that labour productivity declined at an annualized rate of 4.2 per cent in the six years after 2000-01. To explain these outcomes a number of Productivity Commission studies (Topp et al., 2008; Productivity Commission, 2009, 2013) suggested that further advances in mining were being 'masked' by 'resource depletion' (i.e. greater extraction difficulties) and labour allocation to new capital projects, an opinion shared by a number of independent studies (Dolman, 2009; Parham, 2013).

The view that mining productivity is affected by geological factors reflects a more nuanced one than that found earlier in the Production Commission (1998) Inquiry into the coal industry and a series of studies emanating from Flinders University's National Institute for Labour Studies (Wooden, Robertson and Cernaz, 1996; Wooden and Robertson, 1997; Hawke and Robertson, 1999). These held a diminution of union influence and a resort to individual bargaining were a guarantor of sustained productivity increases. While this study will later return to the impact of geological factors on recent coal mining productivity trends, the point to be made here is that in coal mining increased productivity does not always lead to greater prosperity. On the contrary, the reverse often applies. To understand this quandary requires consideration of the three interrelated factors that are arguably the key determinants of coal mining industrial relations: difficulty in providing employee supervision, a tendency towards over-capacity, and the social consequences that stem from geologically fixed supply. Of these three factors, the first relates most directly to productivity given the inherent difficulties in providing direct supervision in either underground labyrinths or the vast spaces of opencut mines (Mauldon, 1929, Beaumont, 1975; Turner, 1982). It is, however, the relationship between productivity and the industry's tendency to over-supply product markets that has historically been the main source of tension. As Mauldon (1929: 152) long ago observed, when prices rise new firms enter the trade 'in a lottery which promises ... to give prizes to all.' When prices fall, newcomers stay rather than amortize investments, exacerbating cyclical imbalances. In these circumstances, increased 
productivity and output tends to both curtail the length of any boom while exacerbating the detrimental effects of price decline. Two main employee responses to this problem have been identified (Clegg, Fox and Thompson, 1964; Gollan, 1963; Turner, 1982). First, by forming unions, employees fought to maintain a floor under wages during periods of falling price. Second, they have historically sought to limit output. At the mine-site level, this involved the imposition of union demarcation lines and individual output restrictions. At an industry-level, unions supported those employers who formed selling cartels or Vends; bodies that sought price maximization through regulated output. What gave union responses force was that the prosperity of entire communities was linked to their efforts, producing what has been described as a 'combative self-consciousness' among geographically distinct coal communities (Mauldon, 1927: 75). Indeed, it is the opinion of virtually every industry study that it is unionism's communal basis that primarily differentiates industrial relations in coal mining from that found elsewhere (Kerr and Siegal, 1954; Gollan, 1963; Williams, 1981). This outcome is, in turn, the result of the third dimension to coal mining industrial relations, the social consequences of geologically fixed supply. While the location of all mining is so determined, coal mining differs in that the value of the extracted commodity is low. In consequence, coal mining normally only occurs when deposits can be worked for long periods, giving coal communities unusual longevity and homogeneity.

Significantly, the study of geography and space has increasingly assumed a central role in mainstream industrial relations. Rather than simply envisioning place as fixed and static, researchers (Herod, 2012; Ellem and Shields, 1999; Ellem and McGrath-Champ, 2012) have come to regard community relationships as contested, shaped by market relationships and labour strategies as well as by personal bonds. If there is one single thing that differentiates the current era of industrial relations in Australian mining from earlier periods it is not the pursuit of enhanced productivity, but rather the managerial reshaping of community-based relationships. Whereas previously employers dealt with the consequences of the 'combative self-consciousness' found in mining communities, in the present they are dealing directly with the source of their past grief. In researching the Pilbara iron ore industry - an industry supplying the same markets as Queensland's coal industry and dominated by many of the same companies - Ellem (2006: 378) observes that 'arguments about place marked the companies' strategies and labor's responses at every step.' If union avoidance and greater control are the incentives for action, the means for social transformation are provided by improved transport 
and longer shift rotations. Prior to the Global Financial Crisis (GFC), this transformation was arguably more complete in the iron ore industry, where company organized FIFO employment prevailed (Ellem, 2003, 2006). By contrast, the well-studied growth of a Drive-in, Drive-out (DIDO) workforce in Central Queensland (Di Milia and Bowden, 2007; Murray and Peetz, 2010; Peetz and Murray, 2011) was an informal rather than a company-directed process, albeit one driven by changed job circumstance. Many of those who commuted from the coast were workers with established ties to the historic coal communities; communities within which many families were migrants from the southern underground sector. The recent decisions of producers such as BHP Billiton to not only utilize FIFO employment but to also avoid recruiting from Central Queensland, therefore, represents not an alteration of industrial relations practice but rather a fundamental recasting.

\section{Methodological Issues}

With the exception of those used for union density, this study's statistics are drawn from Queensland's Department of Natural Resources and Mines (QDNRM). This entity, in one guise or another, has published figures for both employment and production since 1952, relying on annual mine returns. Theoretically, the QDNRM's published figures include on-site contractors. From 2008, however, the QDNRM also required mines to pay a 'safety levy' for those engaged for 14 days or more. These figures, obtained by this study, were at odds with the 'published figures'. Discrepancy is most apparent for the years between 2007-08 and 2011-12, where the 'published figures' show jobs growing from 19,462 to 35,245 (QDNRM, 2013a). The 'safety figures' indicate jobs increased from 23,510 to 42,108 (QDNRM-S\&H, 2013a). But discrepancy is also found in earlier data (see Table 1). It is the QDNRM's opinion that, of the two sets, those recorded for 'safety' purposes are more reliable (QDNRM, 2013c). Nevertheless, labour productivity (i.e. per capita overburden removed, per capita raw coal output, per capita saleable coal output) is calculated on the basis of both data sets. In carrying out such calculations, published production figures are supplemented by statistics on overburden removal provided by QDNRM's Rent and Statistics Unit (QDNRM-R\&S). 
Table 1: Queensland Coal Industry - Two Employment Estimates (QDNRM's Published Figures and Figures from QDNRM's Mine Safety \& Health Unit), 2001-02 to 2012-13*

\begin{tabular}{|l|l|l|l|l|l|l|l|l|l|l|l|l|}
\hline & $\begin{array}{l}2001 \\
-02\end{array}$ & $\begin{array}{l}2002 \\
-03\end{array}$ & $\begin{array}{l}2003 \\
-04\end{array}$ & $\begin{array}{l}2004 \\
-05\end{array}$ & $\begin{array}{l}2005 \\
-06\end{array}$ & $\begin{array}{l}2006 \\
-07\end{array}$ & $\begin{array}{l}2007 \\
-08\end{array}$ & $\begin{array}{l}2008 \\
-09\end{array}$ & $\begin{array}{l}2009 \\
-10\end{array}$ & $\begin{array}{l}2010 \\
-11\end{array}$ & $\begin{array}{l}2011 \\
-12\end{array}$ & $\begin{array}{l}2012 \\
-13\end{array}$ \\
\hline $\begin{array}{l}\text { Published } \\
\text { Figures }\end{array}$ & 10476 & 10713 & NA & NA & 18687 & 18243 & 19462 & 21575 & 24051 & 27595 & 35245 & 23975 \\
\hline $\begin{array}{l}\text { Safety \& } \\
\text { Health } \\
\text { Unit }\end{array}$ & 10047 & 12964 & 15271 & 16786 & 21400 & 20539 & 23510 & 26611 & 26855 & 32568 & 42108 & NA \\
\hline
\end{tabular}

Sources: Department of Natural Resources \& Mines, Annual Coal Statistics, 2002-2012; Department of Natural Resources and Mines (Mine Safety and Health Unit), Communication with Authors [Note: figure for 2012-13 is for December 2013; other figures for financial year]

One issue that may concern is whether our employment statistics accurately map full-time equivalents. Part-time employment is unlikely to have skewed our results. ABS (2013: 40) statistics report minuscule levels of part-time work in this sector, despite encompassing a variety of ancillary workers (off-site clerical workers, construction workers on new mine projects). More problematic is the issue of contractors. Prior to 1996, contractors were mainly used for short-term engagements. But, as we later discuss, contractors now carry out core functions. For this reason, our figures are treated as full-time equivalents. Another potential problem relates to hours of work with a twelve hour day now standard. This means that miners invariably work more annual hours than they did prior to 1996, when an eight-hour day prevailed. However, given the post-2001 focus of our study, a longer working day will be assumed to be the norm. When comparing current levels of productivity with earlier periods, however, the disparity in working hours needs to be borne in mind.

\section{Background: Booms and Busts, 1996-2013}

In Queensland's export coal industry the general tendency towards over-capacity has manifested itself in extreme form. Not only are operations incomparably larger in scale than previous endeavours, they are also now exposed to the vagaries of far distant markets. Admittedly, Queensland benefits from the fact that most of its coal is of the coking (metallurgical) variety used in steel making, a product which historically traded at a 30 to 40 per cent premium to thermal coal. Despite this boon, however, by the early 1980s increased exports were already adversely affecting price. After peaking at US\$59.04 in 1982, the average nominal FOB price for Australian coking coal declined to US $\$ 31.64$ 
per tonne in 2000 (Bowden, 2012: 24) ${ }^{1}$. These falls underpinned a marked shift in employer behaviour as they began to focus more rigorously on costs. Between 1987 and 1995, given the regulatory oversight of the CIT, this involved a series of union-negotiated industry agreements and 'work models' that linked wages to skill levels (Barry, Bowden and Brosnan, 1988). Significantly, previously strong job growth in the industry stalled as prices fell. Between 1985-86 and 1987-88, Queensland employment fell from 10,676 to 9,479 . For the next seven year it fluctuated around these two points before falling precipitously after 1995-96. Within this essentially stagnant job market, employment became increasingly insecure. In the three year period between 1986-87 and 1988-89, for example, those in gainful work fell from 10,342 to 9479 before recovering to 10,028 (QCB, 1988: 44-55). As employment stalled and prices fell, the nine year period of union-negotiated workplace changes (1986-87 to 1995-96) delivered Queensland employers an annualized productivity gain of three per cent as annual per capita saleable output rose from 6994 to 8830 tonnes. Following the passage of the WRA in 1996, however, employers took an increasingly aggressive approach to industrial relations. Employment was cut from 10,962 in $1995-96$ to 8,199 in $2000-01$ (Joint Coal Board \& QDNRM, 2001: 16). Employers also utilized contractors to circumvent the unionized workforce. At Central Queensland's open-cut mines, contractor numbers grew from 416 in 1996 to 2,480 in 2002. Direct employment fell from 6,665 to 3,954 (Bowden, 2004: 504). Twelve hour shifts, worked seven days per week, replaced the eight-hour day. Per capita saleable output rose from 8830 tonnes per annum in 1996 to 16,579 tonnes in 2000-01, a 87.8 per cent increase (QDNRM, 2001: 9).

In 2001, the economic context within which coal mining industrial relations occurred was unexpectedly transformed as the industry entered into a new era of rising export prices. Between 2000-01 and 2005-6, the average FOB price for Queensland coking coal rose from AUD $\$ 62.55$ to AUD $\$ 150.00$ per tonne (see Table 2). Unlike the price spike that followed the GFC, this boom resulted from concentration of ownership during the earlier period of low price; a period that saw the exit of Peabody, Shell and Arco. This left those remaining, led by BHP, with a cartel-like control over supply; a control strengthened in 2001 by the merger of BHP and South African-based Billiton. In 2001 R.W. Kirby, a BHP Billiton executive, observed that 55 per cent of the world's seaborne trade was in the hands of five companies - BHP Billiton, Rio Tinto, Anglo-American, MIM and Fording. Of these, only Canadian-based Fording did not draw supply from Queensland (Kirby, 2001: 3-6).

\footnotetext{
${ }^{1}$ Free on Board (FOB), is the price paid for product loaded at port and inclusive of rail and port costs but excluding shipping and insurance fees.
} 
Table 2: Average FOB Price (AUD\$) for Queensland Coking Coal, 2000-01 to 2012-13*

\begin{tabular}{|l|l|l|l|l|l|l|l|l|l|l|l|l|}
\hline $\begin{array}{l}2000 \\
-01\end{array}$ & $\begin{array}{l}2001 \\
-02\end{array}$ & $\begin{array}{l}2002 \\
-03\end{array}$ & $\begin{array}{l}2003 \\
-04\end{array}$ & $\begin{array}{l}2004 \\
-05\end{array}$ & $\begin{array}{l}2005 \\
-06\end{array}$ & $\begin{array}{l}2006 \\
-07\end{array}$ & $\begin{array}{l}2007 \\
-08\end{array}$ & $\begin{array}{l}2008 \\
-09\end{array}$ & $\begin{array}{l}2009 \\
-10\end{array}$ & $\begin{array}{l}2010 \\
-11\end{array}$ & $\begin{array}{l}2011 \\
-12\end{array}$ & $\begin{array}{l}2012 \\
-13\end{array}$ \\
\hline 62.55 & 77.54 & 71.17 & NA & NA & 150.00 & 123.93 & 121.17 & 310.09 & 151.99 & 209.31 & 219.84 & 141.62 \\
\hline
\end{tabular}

Sources: Department of Natural Resources and Mines, Annual Coal Statistics, 2001-2012. ${ }^{\star}$ Note: figure for 2013 is for December 2013; other figures for financial year.

In 2008-09, new price records were obtained when the average FOB price paid for Queensland coking coal reached AUD\$310.09 per tonne - almost five times the 2000-01 price (see Table 2). Chinese developments explain this good fortune. Whereas China was a net exporter in 2008, by 2010 it was importing 157 million tonnes (IEA, 2011: 41-43). Unfortunately, Chinese demand proved unstable. In 2009-10 the average FOB price obtained for Queensland coking coal fell to AUD\$151.99. While prices then rebounded, between December 2011 and December 2012 the total value of Queensland's coking coal exports collapsed, falling by 41.6 per cent (Queensland Treasury, 2013: 3). A painful restructuring then began. In 2012, BHP Billiton announced the closure of its Norwich Park, Gregory and Crinum mines. In September 2013, Glencore temporarily closed its Collinsville mine, evicting the unionized workforce (McCarthy, 2013: 22). Despite the addition of new mines such as BHP Billiton's Daunia and Caval Ridge, published employment numbers fell from 35,245 in 2011-12 to 23,975 in December 2013 (QDNRM, 2013; QDNRM, 2014: 1).

As prices rose and fell in the period after 1996, so too did productivity, albeit in inverse relationship to both price and employment. In other words, since 1996 rising productivity has been temporally associated with periods of job contraction. Conversely, labour market expansion is correlated with productivity declines. In exploring such trends this study now turns to an analysis of labour productivity at both an industry and mine-site level.

\section{Industry Productivity Trends}

As noted earlier, both the Productivity Commission (Topp et al, 2008; 2009, 2013) and a number of researchers with a past or present affilation with this body (notably Parham, 2004, 2013) have attributed the post-1999 slowdown in mining sector labour productivity to a combination of increased overburden (the earth sitting above the coal seam), lower quality reserves and 'capital lag ', i.e. the delay between capital expenditure on a new project and the eventual return. Discounting productivity results on the basis of such factors is, however, inherently problematic. As is common in mining, 
capital and labour invested in new coal projects, or in extensions of existing mines, often results in little or no monetary return. A case in point is the $\$ 162$ million Wilkie Creek mine expansion project undertaken by Peabody between 2009 and 2013. Slated to add significantly to the mine's production, the project and the mine were abandoned in 2013 without the addition of any new output (Western Downs Regional Council, 2011: 1).

Estimations of the effect of increased overburden are also problematic. Certainly it is true that the shifting of overburden is a barrier to labour productivity in mining, which has historically been understood as the ratio between raw or saleable coal output and the number of workers engaged. Nevertheless, a mine's capacity to efficiently extract coal is dependent upon its capacity to shift overburden. If we are to accept the argument (Topp et al., 2007; Productivity Commission, 2009, 2013; Parham, 2004) that increased overburden is 'masking' otherwise rising productivity, we would logically expect that the amount of overburden being moved per worker would be increasing. This is particularly so given technological gains. The Caterpillar 797F dump trucks introduced at the BHP Mitsubishi Alliance (BMA) pits, for example, had a 400 tonne capacity, 140 tonnes more than the previous generation (Tasker, 2013a: 23). In Figure 1, we test to see whether this occurred by dividing cubic metres shifted by the DNRM's published employment figures. These indicate sharply falling rather than rising per capita performance. Whereas in 2002-03 each mine worker shifted, on average, 95,000 cubic metres, in 2011-12 they moved only 47,000 cubic metres - a decline of almost 50 per cent (QDRM, 2004; QDRM, 2013a; QDNRM - R\&S, 2013). If we had of used the QDNRM's 'safety' figures instead of the 'published' figures, a percentage decline of exactly 50 per cent would have been ascertained with the amount removed per capita falling from 78,000 to 39,000 cubic metres (QDNRM $-\mathrm{S} \& H, 2013)$.

In Figure 1 we also trace the total amount of overburden shifted, again measured in cubic metres. This indicates that in the decade between 2002-03 and 2011-12 the amount of overburden removed in Queensland increased by 63.6 per cent to 163.32 million cubic metres. However, during the previous decade (1992-93 to 2002-03), the overburden task increased by a similar percentage, growing by 57.5 per cent to 101.68 million cubic metres (QDNRM - R\&S, 2013). There is, therefore, no exponential deterioration in the overburden task confronting the industry. 
Figure 1: Queensland Coal Industry - Per Capita Overburden Removed, 200203 to 2011-12* [Total overburden in million cubic metres; per employee overburden in thousand cubic metres]

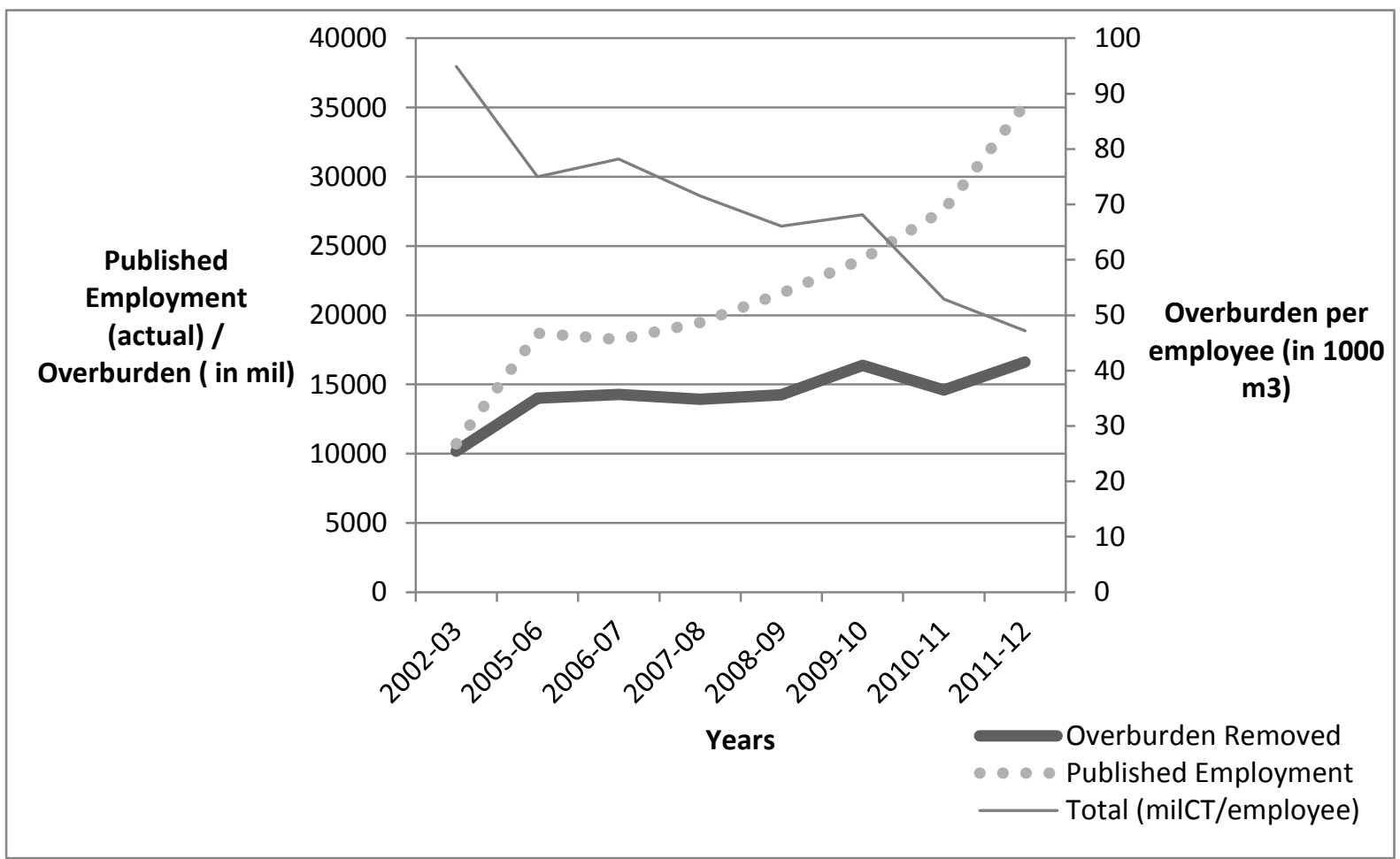

(Source: Queensland Department Natural Resources and Mines - Rent \& Statistics Unit, 2013) *Data on published employment missing for 2003-04 and 2004-05.

The primary measures of labour productivity in coal mining are raw and saleable coal output per capita. In Figure 2, therefore, we compare increases in total raw and total saleable coal output against published job figures for the period 2001-02 to 2011-12. It is evident that raw coal output rose by 31.1 per cent (from 190.1 to 249.1 million tonnes) and saleable coal output increased by 26.5 per cent (from 148.36 to 187.6 million tonnes). During the same period, published employment rose 336 per cent. Using the "safety" figures, we observe a job increase of 419 per cent. Admittedly, consideration of the period 2001-02 to 2011-12 may overstate the gulf that between output and employment due to the fact that production of both raw and saleable coal peaked in 2009-10. This was due, in part, to the wet summers of 2011-12 and, in particular, 2010-11. But even if we restrict ourselves to the pre- 2009 period it is clear that production of raw and saleable output, which grew by 45 and 39 per cent respectively, lagged published employment which grew by 230 per cent and total employment (as recorded for safety purposes), which grew by 267 per cent (QDNRM - R\&S, 2013; QDNRM, 2002; QDNRM, 2004; QDNRM - S\&H, 2013). 
Figure 2: Queensland Coal Industry - Gross Raw and Saleable Coal Output (meuased in million tonnes) and Employment, 2001-02 to 2011-12

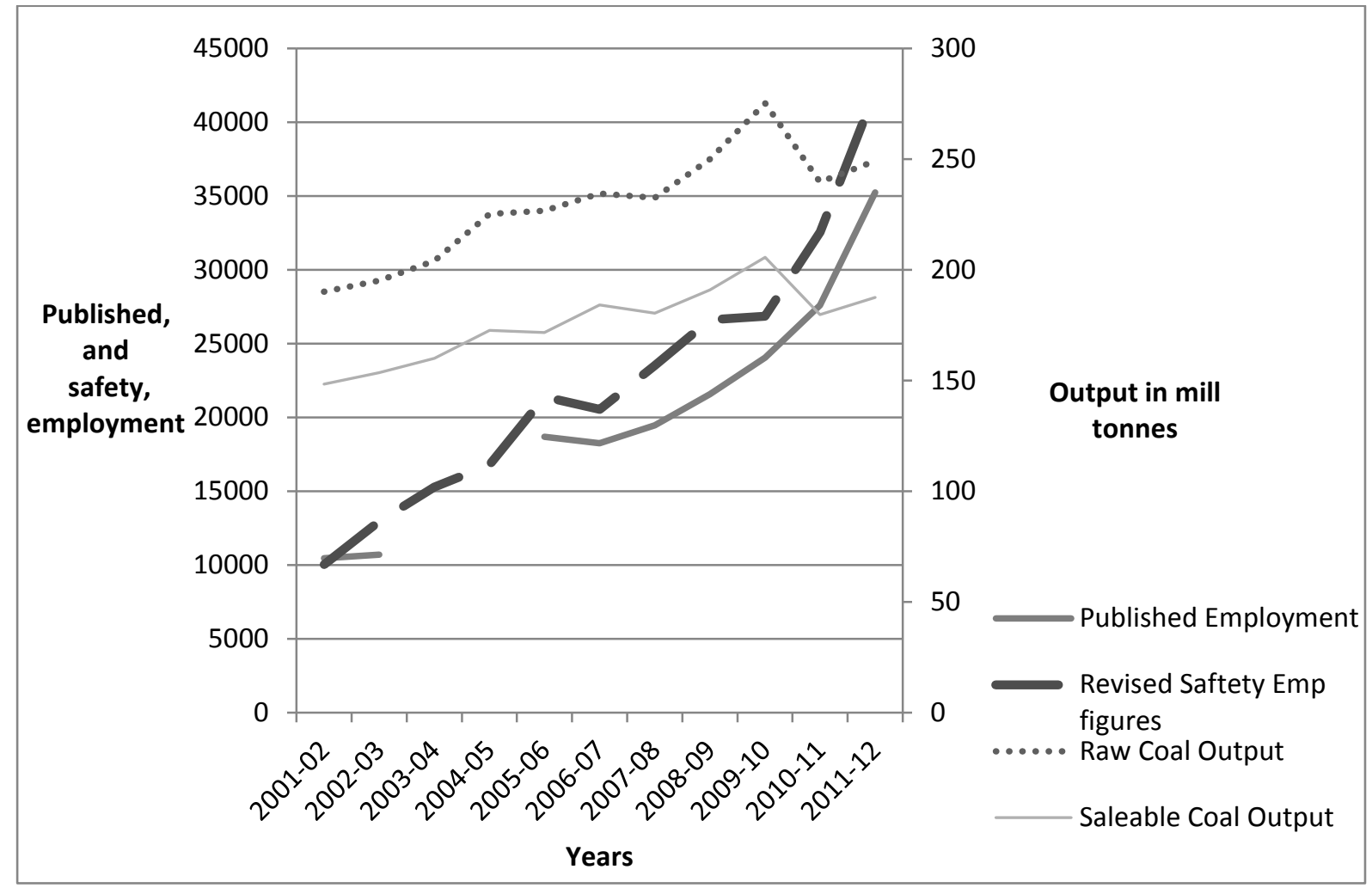

(Source: Queensland Department Natural Resources and Mines - Rent \& Statistics Unit and Mine Safety and Health Unit, 2013) *Data on published employment missing for 2003-04 and 2004-05.

In Figure 3 we shift our focus to per capita output of raw and saleable coal. Using 'published employment' figures, per capita output of raw coal fell by 58 per cent from 18,253 tonnes to 7,067 tonnes between 3001-02 and 2011-12, while saleable output dropped from 15,306 to 5,323 (a 65.2 per cent fall). The 'safety' figures reveal a drop in per capita output of raw coal of 68.7 per cent (from 18,918 tonnes to 5,916 tonnes) and a fall in per capita saleable coal of 69.9 per cent (from 14,767 tonnes to 4,455 tonnes).

Only with the collapse in employment between 2011-12 and December 2013 did the industry witness a partial rebound. With 'published' employment figures indicating a workforce of 23,975 in December 2013 (compared to 35,245 in mid-2012), raw output per employee for the 2013 calendar year rose to 11,609 tonnes. Saleable output climbed to 8,913 tonnes (QDNRM, 2014: 1). Such trends is suggestive of a renewed employer interest in labour productivity that was largely absent during the price boom. 
Figure 3: Queensland Coal Industry - Per Capital Saleable Output (Measured in Thousand Tonnes) Using Published and Safety employment figures, 2001-02 to 2011-12

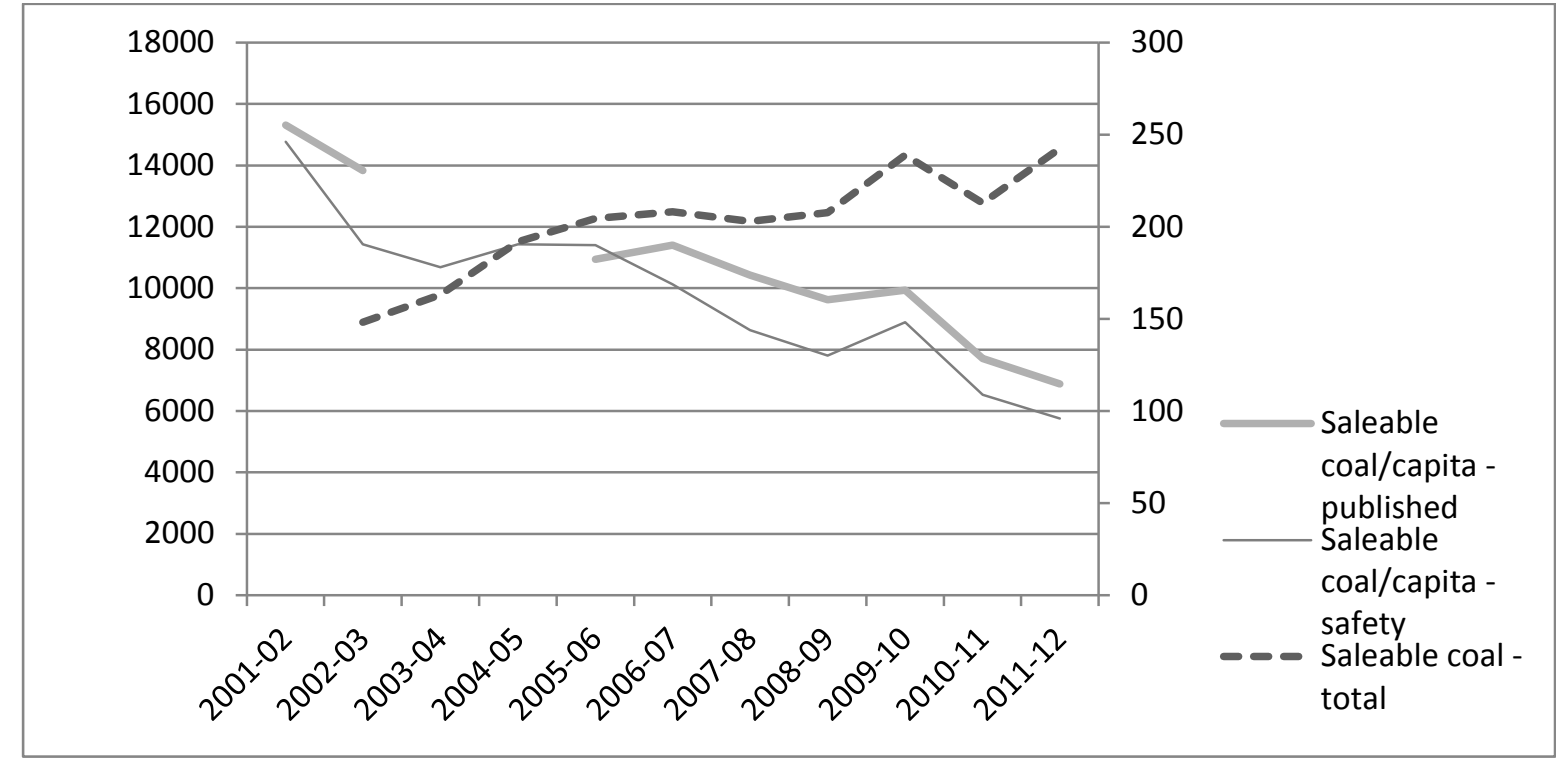

(Source: Queensland Department Natural Resources and Mines - Rent and Statistics Unit and Mine Safety and Health Unit, 2013) *Data on published employment missing for 2003-04 and 2004-05.

The obvious question that emerges when one traces the productivity declines indicated in Figures 1-3 is: Why did employers blithely oversee such declines? The answer is found by shifting our analysis from physical outputs to the monetary value of those outputs. In the falling price environment that characterized the 1990s, profits were obtained by extracting output at the lowest possible cost. However, as Table 3 indicates, between 2000-01 and 2008-09, the export value of the output produced by the average miner soared - even though the tonnage of saleable coal produced per capita collapsed. $^{2}$ In this business environment, even low quality labour was a boon, as long as it shifted some tonnage out the gate. By 2012-13, however, this halcyon period had clearly ended, making the business model that characterized the boom years unsustainable. To further trace trends in both labour productivity and workplace industrial relations, this study now shifts to a mine-site focus for the period between 2008 and 2012, a period when rising prices reached their maximum before abruptly falling.

\footnotetext{
${ }^{2}$ Note: export values are provided as a proxy for total saleable value given the absence of comprehensive figures for domestic sales, much of it which is consumed by adjacent power-stations.
} 
Table 3: Queensland Exports and Value per Employee, 2000-01 to 2012-13* (Two-Year Intervals)

(Export volumes in millions of tonnes)

\begin{tabular}{|l|l|l|l|l|l|l|l|}
\hline & $2000-01$ & $2002-03$ & $2005-06$ & $2006-07$ & $2008-09$ & $2010-11$ & $2012-13$ \\
\hline $\begin{array}{l}\text { Export } \\
\text { Volume }\end{array}$ & 117.56 & 129.22 & 142.86 & 153.36 & 159.97 & 162.47 & 179.78 \\
\hline $\begin{array}{l}\text { Export } \\
\text { Value Billion } \\
\text { AUD }\end{array}$ & $\$ 6.72$ & $\$ 7.98$ & $\$ 17.88$ & $\$ 16.3$ & $\$ 40.96$ & $\$ 29.03$ & $\$ 24.346$ \\
\hline $\begin{array}{l}\text { Employment } \\
\text { Export } \\
\begin{array}{l}\text { Value } \\
\text { employee }\end{array}\end{array}$ & 8467 & 10713 & 18687 & 18243 & 21575 & 27595 & 23975 \\
\hline
\end{tabular}

(Source: Queensland Department Natural Resources and Mines Annual Coal Statistics, 2001-2012) Note: Published employment data missing for 2003-04 and 2004-05. Figures for 2005-06 substituted for 2004-05 *2013 calendar year.

\section{Mine-site Productivity Trends, 2007 to 2012}

The four operations that are the focus of our mine-site analysis - designated mines A, B, C and D are all owned and managed by the same entity (information about each mine was provided by the QDNRM on the basis of anonymity). The significance of the four can be gauged by the fact that in 2012-13 they still provided work for almost a quarter of the state's workforce (QDNRM - R\&S, 2013; QDNRM - S\&H, 2013). As occurred elsewhere, increased employment at our four mines was not matched by commensurate increases in either overburden removed or coal extracted. Whereas the four mines collectively produced 34.9 million tonnes in 2007-08, in 2011-12 they sold only 31.2 million tonnes. The amount of overburden removed at our four mines fell by 9.3 per cent to 393.6 million cubic metres (QDNRM - R\&S, 2013). Nevertheless, total employment - as recorded for the purposes of the industry Safety Levy - grew by 49 per cent to 9,468 (QDNRM - S\&H, 2013).

In Figure 4, we trace the effects of these changes by plotting trends in annual per capita saleable output at our four mines between 2007-08 and 2011-12 against two base lines. The first line (Linear Base 1) is the industry-wide average for 1991 (7,361 tonnes). The second base line (Linear Base Line 2) is the industry average for 2000-01 (16,579 tonnes). As is evident, each of our four mines began 2007-08 with productivity levels below that obtained at an industry level in 1991 and then fell away further over the subsequent five years. At Mine A, per capita saleable output fell from 6,881 to 3,300 tonnes as employment rose from 1,584 to 2,576 . At Mine $B$, it dropped from 4,308 to 2,814 tonnes as job numbers increased from 1,323 to 2,061. At Mine C per capita output fell from 
4,799 to 3,327 tonnes as employment expanded from 1,688 to 2,134. At Mine D, employment grew from 1,758 to 2697 as per capita output fell from 5,176 to 3,634 tonnes (calculated from QDNRM R\&S, 2013 and QDNRM - S\&H, 2013).

Figure 4: Four Sample Mines - Average Annual Per Capita Saleable Output, 2007-08 to 2011-12 (Measured Against Industry Average for 1991, 2001-02)

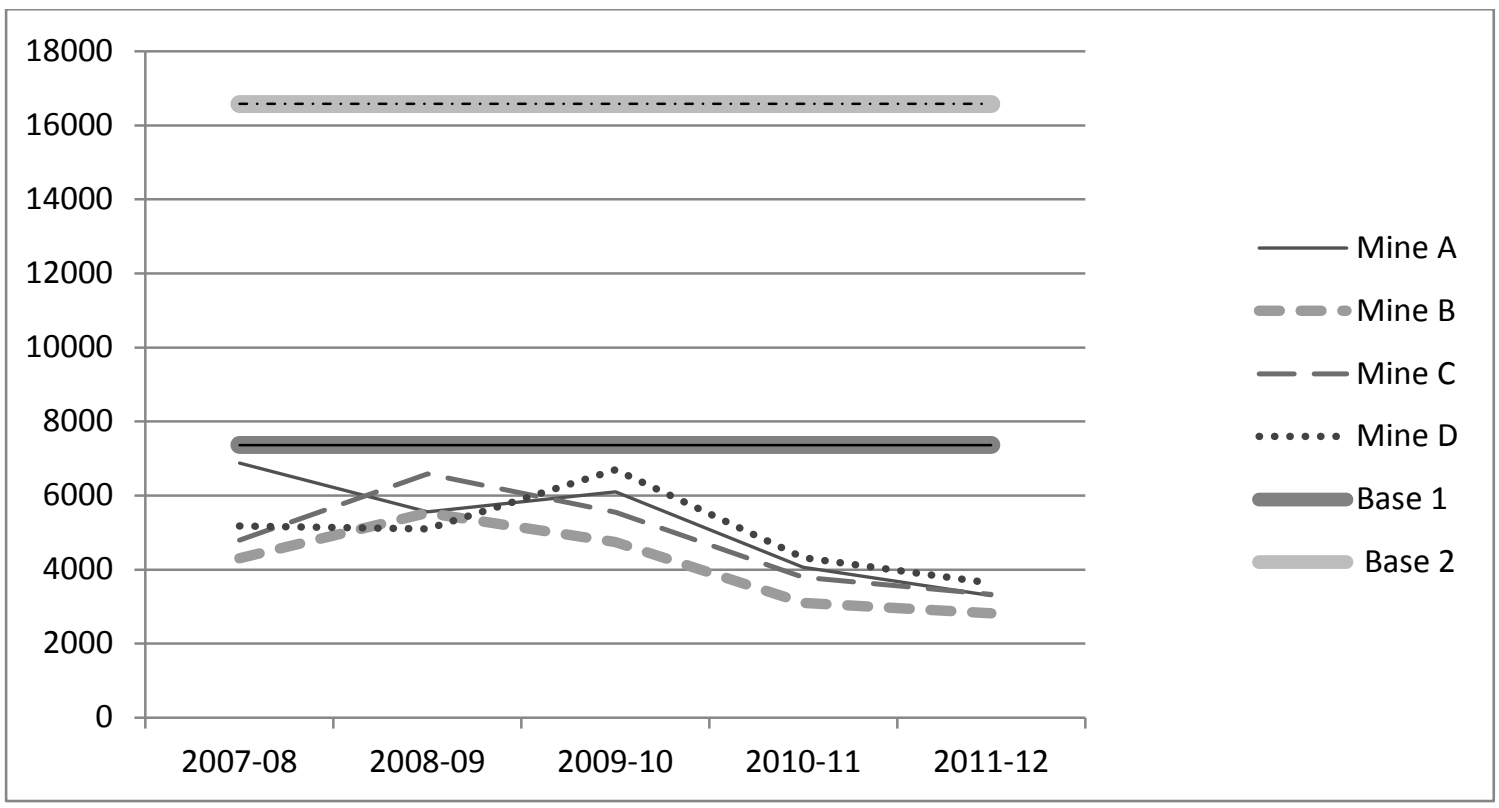

(Source: Queensland Department Natural Resources and Mines - Mine Safety and Health Unit 2013) [Note: per capita output measured in thousands of tonnes]

While it is not possible to conclusively identify a single or even multiple causal factor as being responsible for the declining per capita outputs, one correlation is nevertheless clear. Increased employment across the four mines between 2007-08 and 2011-12 was almost entirely due to increased contractor numbers. As Table 4 reveals, the number of contractors (and their employees) at the four mines grew by 89.9 per cent to 5,970 . Whereas in 2007-08 the share of the mine-site workforce held by contractors ranged between a low of 44 per cent (Mine D) and a high of 54.2 per cent (Mine A), by 2011-12 the range was between 61.2 per cent (Mine B) and 71.7 per cent (Mine C). 
Table 4: Contractors and Employees - Sample Mines, 2007-08 to 2012-13

(Figures in parenthesis indicate percentage of contractors at mine)

\begin{tabular}{|c|c|c|c|c|c|c|c|}
\hline & & 2007-08 & 2008-09 & $2009-10$ & $2010-11$ & 2011-12 & 2012-13 \\
\hline \multirow{3}{*}{$\begin{array}{c}\text { Mine } \\
\text { A }\end{array}$} & Employees & 725 & 720 & 692 & 749 & 841 & 931 \\
\hline & Contractors & 859 (54.2) & 1157 (61.6) & 1192 (63.3) & $\begin{array}{c}1381 \\
(64.8)\end{array}$ & $\begin{array}{c}1735 \\
(67.4)\end{array}$ & $\begin{array}{c}1322 \\
(58.7)\end{array}$ \\
\hline & Total & 1584 & 1877 & 1884 & 2130 & 2576 & 2253 \\
\hline \multirow{3}{*}{$\begin{array}{c}\text { Mine } \\
\text { B }\end{array}$} & Employees & 694 & 586 & 583 & 633 & 800 & 908 \\
\hline & Contractors & $629(47.5)$ & $662(53.0)$ & 742 (56.0) & $1120(63.9)$ & 1261 (61.2) & 991 (52.4) \\
\hline & Total & 1323 & 1248 & 1325 & 1753 & 2061 & 1899 \\
\hline \multirow{3}{*}{$\begin{array}{c}\text { Mine } \\
\text { C }\end{array}$} & Employees & 807 & 830 & 831 & 840 & 891 & 904 \\
\hline & Contractors & 881 (52.2) & 507 (37.9) & 701 (45.8) & 979 (53.8) & $1243(71.7)$ & $904(50)$ \\
\hline & Total & 1688 & 1337 & 1532 & 1819 & 2134 & 1808 \\
\hline \multirow{3}{*}{$\begin{array}{c}\text { Mine } \\
\text { D }\end{array}$} & Employees & 984 & 1098 & 931 & 980 & 966 & 1098 \\
\hline & Contractors & $774(44.0)$ & $882(44.5)$ & 1056 (53.1) & $1389(58.6)$ & 1731 (64.2) & $1333(54.8)$ \\
\hline & Total & 1758 & 1980 & 1987 & 2369 & 2697 & 2431 \\
\hline \multirow{3}{*}{$\begin{array}{l}\text { Four } \\
\text { Mine } \\
\text { Totals }\end{array}$} & Employees & 3210 & 3234 & 3037 & 3202 & 3498 & 3831 \\
\hline & Contractors & $3143(49.5)$ & 3208 (49.8) & 3691 (54.9) & $5970(65.1)$ & $5970(63.1)$ & 4550 (45.3) \\
\hline & Total & 6353 & 6442 & 6728 & 9172 & 9468 & 7551 \\
\hline
\end{tabular}

(Source: Queensland Department of Natural Resources and Mines)

In explaining the increase in contractor numbers across our four mines we firstly note the extent to which core activities, previously the domain of employee miners, were out-sourced. This entrenched a practice the beginnings of which were observed by Waring in the early 2000s (Waring, 2003). At Mine D, the largest of the four mines, slightly over half the contractor workforce (685 out of 1,333) were employed by a single contractor, Downer EDI, whose workforce operated both drill and blast services and seven truck-shovel fleets at Mine D's pre-strip operation. For Downer EDI, which was also a contractor at Mine A, its contract at Mine D was its largest in eastern Australia, being valued at more than $\$ 400$ million per year (Downer EDI, 2013; Macnamara, 2013: 20; Garvey, 2013: 19). At Mine C, overburden removal was also largely contracted out, this time to Leighton Contractors. By 2012 Leighton‘s permanent workforce at Mine C stood at 260 (Leighton, 2013a). In 2008, Leighton Contractors also secured a $\$ 264$ million extension of an overburden removal contract at Mine B (Leighton, 2013b). Subsequently, Mine B pre-stripping passed to HSE, which by 2013 was employing 360 permanent workers on-site - 39.8 per cent of the mine's contract workforce (HSE Group, 2013). 
As we discuss further below, increased engagement of contractors by coal operators was primarily undertaken as part of a long-term strategy directed towards the circumvention of the unionized workforce. Any managerial hopes that this would also deliver a productivity boom proved misplaced. Forced to compete in the same labour market as the mining companies themselves, there is little to indicate that contractors and their employees were either more or less productive or more or less cost effective than employee miners. As one observer (Fitzgerald, 2013: 24) noted, by 2012 it was widely considered that the cost advantage of contractors was 'pretty much ... zero.' As coal prices waned after 2011, so too did coal owner enthusiasm for contractors. In May 2013, BHP Billiton executive, Gideon Oberholzer, informed analysts that his company intended 'a reduction in contractor usage' (Tasker, 2013b: 18). This shift is also evident at our four mines, which saw employee miners recoup a 19.4 per cent share of the four-mine workforce between 2010-11 and 2012-13.

\section{Recasting Industrial Relations}

If we look solely at the issue of productivity, then the years since 2001 stand in marked contrast to the previous decade. Whereas productivity more than doubled between 1991 and 2001 in a job market characterized by first static and then falling employment, the ensuing decade saw saleable output per employee fall to less than a third of the 2001 peak in the context of rapid labour force expansion. The experience of these latter years therefore cautions against assumptions, forcefully advocated by the Productivity Commission $(1998,2009,2013)$, that a labour relations environment that imposes less restrictions on management is a guarantor of higher productivity. Until 1 July 2009, when Labor's Fair Work Act became operational, employers operated either under the WRA or the even more managerial-friendly WorkChoices Act 2005. Union density also crumpled, falling from 82.5 per cent in 1996 to 39.8 per cent in 2013 (ABS, 1997, 2014). However, this did not lead to long-term productivity increases. The industry, moreover, remained bedevilled by the underlying tendency towards overcapacity. Not only had this tendency reasserted itself by 2011, senior managers and investors also understood that a renewed productivity drive would exacerbate rather than alleviate this problem. At a BHP Billiton investor meeting in 2014, a Goldman Sachs analyst observed that 'this productivity-led cycle that you're embarking upon' would drive 'the coking coal price down.' In response, BHP Billiton's Chief Executive Office, Andrew Mackenzie, conceded the point, nevertheless adding: 'Once we've installed something, we believe in ... ramp[ing] them up to the maximum extent possible' (BHP Billiton, 2014: 10-11). 
Despite the negative productivity growth that characterized the Queensland coal sector between 2001 and 2012, the industry nevertheless witnessed a fundamental reshaping of industrial relations. Two stages in this process can be identified. In the first, between 2001 and 2011, the primary emphasis was on avoiding the unionized workforce through a resort to contractors. Increasingly, management outsourced core mining activities such as pre-stripping and drilling. A visit to the websites of any major mining contractor - Thiess, HSE, Leighton Contractors - reveals the extent to which mining work is now the domain of contractors rather than mine owners. Among the recent projects of Leighton Contractors are a five year contract (2007-2012) at the Sonoma mine that employed 220 and was valued at $\$ 500$ million; a two year contract (2010-2013) at Dawson North that gave work to 150; and a 15 month contract (June 2012 - September 2013) at Peabody's Moorvale mine, valued at $\$ 125$ million (Leighton Contractors, 2013). Thiess's projects included the full operation of BHP Billiton Mitsui's South Walker Creek (employing 224 Thiess staff) and a contract at Westfarmers' Curragh North that gave work to another 240 (Thiess, 2013). As has been well documented (Peetz and Murray, 2011; Di Milia and Bowden, 2007), the growth of outsourcing and longer shift rosters was widely associated with the emergence of a DIDO workforce as many workers opted to base themselves in adjacent coastal communities rather than mining townships. However, even though an estimated 40 per cent of the Central Queensland coal workforce was commuting to and from the coast by 2011 (BMA, 2011:19), there is nothing to suggest that this resulted from deliberate managerial strategy. Instead, mine operators developed an agnostic attitude to the DIDO phenomenon. Whether one became a DIDO worker, or remained a permanent resident, was a matter of individual choice - albeit one influenced by changed employment circumstance.

While management's attitude towards the DIDO phenomenon may have been agnostic, the emergence of a FIFO workforce was different. Rather than being a matter of informal worker choice, a FIFO workforce only emerged in Queensland due to employer action. This was first indicated when in 2011 the BHP Billiton-led BMA consortium successfully applied to the then Bligh Labor Government to have its proposed Caval Ridge mine staffed on a 100 per cent FIFO basis with half sourced from the Cairns region and the other half from Greater Brisbane (BMA, 2011: 3). While at work at Caval Ridge, which began operations in 2014, the FIFO workforce is housed on-site at the Buffel Park Accommodation Village. Local residence is specifically ruled out. Under the mine's Operational Plan, it is stated that: 'Should an employee ... decide that a residential position would better suit their 
individual circumstances, that employee would be encouraged to apply for a residential role on one of BMA's existing operations (BMA, 2011: 23). Similar provisions apply at BMA's nearby Daunia mine, which began operations on a FIFO basis in September 2013. Perhaps unsurprisingly, Caval Ridge and Daunia miners were soon the source of complaint. One long-term Moranbah resident advised Shane Knuth, a Katter Australia Party politician, that in order to gain employment he had to disguise his home location. In consequence, he now 'flies to Brisbane before their rostered starts and then flies back to Moranbah and lives in the camp for the rostered shift'. At the end of his shift, he follows the same steps in reverse (Queensland Parliament, 2014: 1549). It is also alleged that, under the conditions of their employment, Daunia and Caval Ridge miners are prohibited from visiting nearby Moranbah. One informed Knuth that: 'He could not go to Coles or McDonald's and, if he did, he would be fired.' While BMA disputes such allegations, what is evident is that Daunia and Caval Ridge miners have little capacity for local socialisation given that all aspects of their movement from home airport to company accommodation is organized and overseen at every stage by management (BMA, 2011: 23). Once in camp, chance interaction with the predominately unionized workforce at the Peak Downs mine, located between the Daunia and Caval Ridge leases, is also excluded as workers move to and from company accommodation via internal roadways.

In outlining the reasons behind the decision to operate its new projects on a FIFO basis, BHP Billiton's Coal Division President, Dean Dalla Vale, declared that 'improving the productive performance ... starts with changing the culture and mind-set' (Dalla Vale, 2014: 7-8). Clearly, cultural change rather than recruitment difficulties appears the driver of BHP Billiton's recent initiatives. For unlike the situation that prevails in Western Australia's Pilbara, the Central Queensland coal mines are not geographically remote. Moranbah, Central Queensland's largest community, can be reached via a two hour flight from Brisbane or a three hour drive from Mackay. Indeed, it is the coalfields' ease of access from the coast that fuelled the DIDO phenomenon. Nor are the Daunia and Caval Ridge mines, which lie 15 kilometres to Moranbah's south, remote from established facilities. Deposits at both mines could have been accessed through an extension of the Peak Downs mine, a circumstance which has prevailed on numerous prior occasions. Similarly, vacancies at the two new mines could have been filled by those left jobless by the closure of BHP's Norwich Park, Gregory and Crinum pits. All this creates suspicion that BHP Billiton's envisioned future revolves around the displacement of its resident, unionized workforce by a non-union FIFO population that will mine all new deposits. Nor is 
BHP Billiton alone in dispensing with a resident workforce. In August 2013, Glencore closed its Collinsville mine rather than continue employment of its unionised workforce. Following the closure, the CFMEU's District President, Stephen Smyth, stated that he 'expected the dispute to end up as the "Patrick's of the Outback" with non-union labour brought in to break the deadlock' (McCarthy, 2013: 22). Management is, in short, reshaping Central Queensland's social landscape - a reshaping for which there are no prior precedents in the history of the Australian coal industry.

\section{Conclusion}

In 2001, few could have predicted the events that were to transpire in the Queensland coal industry in the ensuing thirteen years. Given that the decade and a half preceding 2001 had been characterized by falling coal prices, declining employment, rising productivity and an increasingly embittered relationship between the coal unions and employers, a continuation of all these established trends then seemed the most likely outcome. How then, in 2014, are we to make sense of not only the last 13 years but of the entire last quarter century in ways that allow prediction of the likely future path of industrial relations in this industry? The key to this conundrum is to look beyond the surface movements to comprehend the underlying currents that have always characterized coal mining. At this deeper level, we have argued, three key factors are at play: the difficulty of supervising employees in coal mines, a tendency to over-supply product markets and the social consequences of geologically-fixed supply. With regard to the first of these, supervision of coal miners, the events of the last 25 years in general, and the last 13 years in particular, suggest it is far easier to extract increased labour productivity in a falling job market than a rising one. Since 1996, when both coal prices and employment have fallen (1996-2001 and 2011-2013), productivity has risen. Conversely, when employment and coal prices rose (2001-2011), productivity fell. The only partial exception to this rule applies to the situation that prevailed during the era when workplace change occurred within a union-negotiated framework (1987-1995). During this period, employment stagnated rather than fell. Even this era was, however, characterized by increasingly insecure employment with marked annual fluctuations. By contrast, it is difficult to ascertain any clear link between increased labour productivity and industrial relations 
practices. Since the mid-1980s, rising productivity has been associated with unionnegotiated 'work models' (1987-1995) as well as periods when employers resorted to individual bargaining and increased utilization of contractors (1996-2001 and 2011-2013). Yet the latter practices were also associated with the long period of declining productivity (2001-2011). We can thus conclude that the state of the labour market is the best indicator of likely trends in labour productivity.

The second thing that we can conclude is that there is no causal link between increased productivity and industry prosperity. On the contrary, the pattern evident over the last 25 years suggests that rather than it being the case that increased productivity creates prosperity, it would appear that industry prosperity drives falling productivity. When prices rose dramatically after 2001, employers promptly abandoned interest in productivity, happily increasing employment for relatively modest output gains.

While price, productivity and prosperity have risen and fallen over recent decades, the one constant has been employer campaigns to circumvent the consequences of geologically-fixed supply; consequences that have historically manifested themselves in coal mining community support for trade unionism and collective employment responses. In their attempts to overcome the community-based collective traditions of coal mining, employers have engaged in two main strategies since 2001. Between 2001 and 2011, employers resorted to contractors to circumvent the unionized workforce. Since 2011, certain employers (BHP Billiton and Glencore) have resorted to FIFO workforces to circumvent not only the unionized workforce but also the coal mining communities. While the outcome of this strategy cannot be foreseen, the one thing that we can predict is that it will only be associated with increased productivity during times of labour market shrinkage. 


\section{References}

Australian Bureau of Statistics (1997) Trade Union Members, 1996. Canberra: Australian Bureau of Statistics, Cat. No. 6325.0.

Australian Bureau of Statistics (2002) Employee Earnings, Benefits and Trade Union Membership: August 2001. Canberra: Australian Bureau of Statistics, Cat. No. 6310.0

Australian Bureau of Statistics (2010) Australian Labour Market Statistics: October 2010. Canberra. Australian Bureau of Statistics, Cat. No. 6105.0

Australian Bureau of Statistics (2014) Employee Earnings, Benefits and Trade Union Membership: August 2013. Canberra: Australian Bureau of Statistics, Cat. No. 6310.0

Australian Council of Trade Unions / Trade Development Commission (1987) Australia Reconstructed. Canberra: Australian Government Publishing Service.

Barry M, Bowden B and Brosnan (1998) The Fallacy of Flexibility: Workplace Reform in the Queensland Open Cut Coal Industry. Sydney: Allen \& Unwin.

Barry, M and Waring P (1999) "Shafted": labour productivity and Australian coal miners Journal of Australian Political Economy, 44, pp. 89-112.

Beaumont, P B (1975) Conflict in coal: the NSW experience. Journal of Industrial Relations. 17 (1): 44-59.

BHP Billiton (2014) BHP Billiton Interim Results: Transcript - Investor Briefing, 18 February. http://www.bhpbilliton.com/home/investors/reports/Documents/2014/140218 InvestorAndAnal ystBriefingTranscript0.pdf Accessed 18 July 2014.

BHP Billiton Mitsubishi Alliance (2011) Caval Ridge Mine: Operational Workforce Change Request 4 - Submission to Queensland Coordinator-General. BHP Billiton Mitsubishi Alliance, 14 June.

Bowden B (2000) A collective catastrophe: productivity maximisation and workplace bargaining in the Australian coal industry. Journal of Industrial Relations 42 (3): 364-382.

Bowden B (2003) Regulating outsourcing: the use of contractors on the Central Queensland coalfields, 1974-2003. Labour \& Industry 14(1): 41-57.

Bowden, B (2012) A history of the Pan-Pacific coal trade from the 1950s to 2011: exploring the longterm effects of a buying cartel. Australian Economic History Review. 52 (1): 1-24.

Business Council of Australia (2005) Workplace Relations Action Plan: For Future Prosperity. Melbourne: Business Council of Australia.

Clegg, H Fox, A and Thompson, A (1964) A History of British Trade Unions Since 1989. Oxford, Clarendon Press.

Coal Services Pty Ltd. (2013) Then and Now: Annual Report 2013. http://www.coalservices.com.au/MessageForceWebsite/Sites/340/Files/Coal\%20Services 20 13 Annual Report.pdf Accessed 18 July 2014.

Commonwealth Treasury (2009) Raising the level of productivity growth in the Australian economy. Economic Roundup. 3: 47-66.

Dalla Valle, D (2014) Address to Committee for Economic Development of Australia. 2 April. http://www.bhpbilliton.com/home/investors/reports/Documents/2014/140402 BHPBillitonDisc ussestheGlobalOutlookforCoalatCEDA Speech.pdf Accessed 18 July 2014.

Di Milia L and Bowden B (2007) Unanticipated safety outcomes: shiftwork and drive-in, drive-out workforces in Queensland's Bowen Basin. Asia Pacific Journal of Human Resources. 45 (1): 100-112.

Dolman,B (2009) What happened to Australia's productivity surge? Australian Economic Review. 42 (3): 243-263.

Dolman, B Lu, L and Rahman, J (2006) Understanding productivity trends. Economic Roundup. 1: 3552. 
Downer EDI (2013) Mining Case Studies: Goonyella-Riverside, http://www.downergroup.com/Sectors/Resources/Resources-Mining/resourcesmining.aspx, Accessed 3 October 2013.

Ellem B (2003) New unionism in the old economy: community and collectivism in the Pilbara. Journal of Industrial Relations 45 (4): 423-441.

Ellem B (2004) Hard Ground: Unions in the Pilbara. Port Headland: Pilbara Mineworkers Union.

Ellem, B (2006) Scaling labour: Australian unions and global mining. Work, Employment and Society. 20 (2): 369-387.

Ellem, B and Shields, J (1999) Rethinking regional industrial relations: Space, place and the social relations of work. Journal of Industrial Relations. 41 (4): 536-560.

Ellem, B and McGrath-Champ, S (2012) Labor geography and labor history: insights and outcomes from a decade of cross-disciplinary dialogue. Labor History. 53 (3): 355-372.

Fitzgerald B (2013) Mining support firms look for light at the end of the tunnel. Australian, 25-26 May, 23-24.

Garvey, P (2013) Coal gloom as Glencore cuts 450 jobs. Australian, 28 June.

Gollan, R (1963) The Coalminers of New South Wales. Melbourne: Melbourne University Press.

Hancock, K (2012) Enterprise bargaining and productivity. Labour \& Industry. 22 (3): 289-302.

Hancock, K Bai, T Favel, J and Lane, A (2007) Industrial Relations and Productivity in Australia. Adelaide: National Institute of Labour Studies, Flinders University.

Hawke, A and Robertson, F (1999) Enterprise Bargaining in the Coal Industry: Implications for Work Practices. Adelaide: National Institute for Labour Studies, Flinders University.

Herod, A (2012) Workers as geographical actors. Labor History. 53 (3): 335-353.

HSE Group (2013) Saraji Mine Site, www.hsegroup.com.au/sections/Projects Mining Services/Saraji Mine Site BMA Accessed 3 October 2013.

International Energy Agency (2011) Coal: Medium Term Market Report, 2011. Paris: International Energy Agency.

Joint Coal Board and Queensland Department of Natural Resources and Mines (2001), Australian Black Coal Statistics 2000. Sydney, Joint coal Board.

Kerr, C and Sigel, A (1954) The interindustry propensity to strike - and international comparison. In A Kornhauser, R Dubin and A Ross (eds.) Industrial Conflict. New York: McGraw-Hill, 189-212.

Kirby, R W (2001) Steel Making Raw Materials: Opportunities \& Challenges, Tokyo: Australia Japan Joint Business Conference, October.

Leighton (2013a) Peak Downs www.leightoncontractors.com.au/projects/peak-downs/ Accessed 3 October 2013.

Leighton (2013b) Peak Downs and Saraji Mine (Stage 6) www.leighton.com.au/ourbusiness/projects/completed-projects/peak-downs-and-saraji-mine-stage-6 Accessed 3 October 2013.

Mauldon, F R E (1927) A Study in Social Economics: the Hunter River Valley. Melbourne: Robertson \& Mullens.

Mauldon, F R E (1929) The Economics of Australian Coal. Melbourne: Melbourne University Press.

McCarthy, J (2013) Open cut bled dry. Courier Mail, 6 September.

Macnamara, L (2013) Downer cuts back as work dries up. Australian, 27 June.

Murray G and Peetz, D (2010) Women of the Coal Rushes. Sydney: University of New South Wales Press.

Peetz, D (2006) Hollow shells: the alleged link between individual contracting and productivity growth. Journal of Australian Political Economy. 56: 32-55. 
Peetz, D (2012) Does industrial relations policy affect productivity? Australian Bulletin of Labour. 38 (4): 268-292.

Peetz D and Murray G (2011) 'You get really old, really quick': Involuntary long hours in the mining industry. Journal of Industrial Relations. 53 (1): 13-29.

Productivity Commission (1998) The Australian Black Coal Industry Report. Vol. 1. Canberra: AusInfo.

Productivity Commission (2009) Australia's Productivity Performance: Submission to the House of Representatives Standing Committee on Economics. Melbourne: Productivity Commission.

Productivity Commission (2013) Productivity Update. East Melbourne: Productivity Commission.

Parham, D (2004) Sources of Australia's productivity revival. Economic Record. 80: 239-257.

Parham, D (2013) Australia's productivity: past, present and future. Australian Economic Review. 46 (4): 463-472.

Queensland Coal Board (1988) Report of the Queensland Coal Board, 1987-1988. Brisbane: Queensland Coal Board.

Queensland Department of Mines and Energy (2009) Queensland Coal Statistics: 2008-09. Brisbane: Department of Mines and Energy.

Queensland Department of Natural Resources and Mines (2001) Queensland Coal Industry Review, 2000-01 (Brisbane: Queensland Department of Natural Resources and Mines)

Queensland Department of Natural Resources and Mines (2002) Queensland Coal Industry Review, 2001-02 (Brisbane: Queensland Department of Natural Resources and Mines)

Queensland Department of Natural Resources and Mines (2004) Queensland Coal Industry Review, 2003-04 (Brisbane: Queensland Department of Natural Resources and Mines)

Queensland Department of Natural Resources and Mines (2012) Queensland's Coal - Mines and Advanced Projects. $\quad$ Accessed $26 \quad$ September 2013: http://mines.industry.qld.gov.au/assets/coal-pdf/new coal min adv proj.pdf

Queensland Department of Natural Resources and Mines (2013a) Queensland Quarterly Coal Statistics: December 2012. Accessed 26 September 2013: http://mines.industry.qld.gov.au/assets/coal-stats-pdf/qrl 0412.pdf

Queensland Department of Natural Resources and Mines (2013b) Queensland Annual Coal Statistics: $\quad 2011-12 . \quad$ Accessed 26 September http://mines.industry.qld.gov.au/assets/coal-stats-pdf/fyr 1112.pdf

Queensland Department of Natural Resources and Mines (2013c), Email Communication with Authors, 20 August.

Queensland Department of Natural Resources and Mines - Rent and Statistics Unit (2013), Production Statistics for the Queensland Coal Industry, 2001-02 to 2011-12. Email Communications with Author, 13 June and 19 June.

Queensland Department of Natural Resources and Mines - Mine Safety and Health (2013a), Employment Statistics for the Queensland Coal Industry, 2001-02 to 2011-12. Private Communications with Author, 20 August.

Queensland Department of Natural Resources and Mines - Mine Safety and Health (2013b), Employment and Production Statistics for Four Queensland Coal mines, 2007-08 to 2011-12. Private Communications with Author, 21 August.

Queensland Department of Natural Resources and Mines (2014) Queensland Coal Statistics for 2013 Calendar Year. http://mines.industry.qld.gov.au/assets/coal-stats/12-month-reports/coal-statscal-year-2013.pdf Accessed 18 July 2014.

Queensland Parliament (2014) Parliamentary Record of Proceedings. 20 May. Accessed 25 July 2014: http://www.parliament.gld.gov.au/work-of-assembly/sitting-dates/dates/2014/2014-05$\underline{20}$

Queensland Treasury (2013) Queensland Economic Review: January 2013. Brisbane: Queensland Treasury. 
Tasker, S (2013a) Technology to drive BHP productivity. Australian, 31 May.

Tasker, S (2013b) Heads chopped as miners cut costs. Australian, 29 July.

Thiess (2013) Coal Mining Projects. www.thiess.com.au/capabilities/projects/search?keywords=\&sector=mining\&capability=\&curr ent=\&region= Accessed 6 October 2013.

Topp, V, Soames L, Parham D and Bloch H (2008) Productivity in the Mining Industry: Measurement and Interpretation. Melbourne: Productivity Commission.

Turner, J W (1982) Coal Mining in Newcastle 1801-1900. Newcastle, Newcastle City Council.

Waring, $P$ (2003) The nature and consequences of temporary and contract employment in the Australian black coal mining industry, Labour and Industry, 14 (2): 83-96.

Williams, C (1981) Opencut: the working class in an Australian mining town. Sydney: Allen \& Unwin.

Wooden, M, Robertson, F and Cernaz, R (1996) Coal Industry Awards and Agreements and the Implications for Work Practices and Working Conditions. Adelaide: National Institute for Labour Studies, Flinders University.

Wooden, M and Robertson, F (1997) Employee Relations Indicators: Coal Mining and Other Industries Compared. Adelaide: National Institute of Labour Studies, Flinders University. 